\title{
Penerapan Factor Analysis Untuk Mereduksi Variabel Sektor Perikanan Kabupaten/Kota di Jawa Timur
}

\author{
Farizi Rachman ${ }^{1}$ \\ ${ }^{1}$ Jurusan Teknik Kelistrikan Kapal,Politeknik Perkapalan Negeri Surabaya \\ farizirachman@ppns.ac.id
}

diterima tanggal : 10 April 2018 disetujui tanggal : 10 Mei 2018

\begin{abstract}
Abstrak
Penelitian ini akan membuat analisis faktor perikanan laut dan perairan umum di Jawa Timur. Analisis ini merupakan kelanjutan dari pemetaan sektor perikanan Kabupaten/Kota di Jawa Timur dengan menggunakan Fuzzy K-means. Analisis faktor adalah sebuah teknik yang digunakan untuk mencari faktor-faktor yang mampu menjelaskan hubungan atau korelasi antara berbagai indikator independen yang diobservasi. Tujuan dari analisis faktor adalah untuk menggambarkan hubunganhubungan kovarian antara beberapa variabel yang mendasari tetapi tidak teramati, kuantitas random yang disebut faktor. Berdasarkan analisis faktor dengan menggunakan analisis factor maka didapatkan bahwa 70,150\% persoalan perikanan laut yang terdiri dari Sembilan variabel bergantung pada dua faktor utama dan saling independen. Sedangkan analisis faktor untuk perariran umum didapatkan bahwa 70,144\% persoalan perairan umum yang terdiri dari Sembilan variabel bergantung pada dua factor utama dan saling independen. Proses analisis faktor ini melalui proses rotasi dengan varimax.
\end{abstract}

Kata Kunci: Perikanan, Analisis faktor, Varimax

\begin{abstract}
This research will make variable factor analysis, marine fishery and public waters in East Java. This analysis is a continuation of mapping of fishery sector of City in East Java by using Fuzzy Kmeans. Factor analysis is a technique used to look for factors that can explain the relationship or correlation between the various independent indicators that are observed. The purpose of factor analysis is to illustrate the covariance relationships between some underlying but unobserved variables, random quantities called factors. Based on factor analysis using factor analysis it is found that 70,150\% marine fishery problem consist of Nine variables depend on two main factor and mutual independent. While factor analysis for general waters found that $70.144 \%$ of the general waters problem consisting of Nine variables depend on two main factors and is independent. The process of analyzing this factor through the rotation process with varimax.
\end{abstract}

Keywords: Perikanan, Analisis faktor, Varimax

\section{PENDAHULUAN}

Berdasarkan data statistik tahun 2014, diketahui bahwa distribusi Produk DomestikRegional Bruto Jawa Timur diperoleh dari sektor industri dan pengolahan sebesar $28,90 \%$, sektor perdagangan, hotel dan restoran sebesar $17,24 \%$, dan yang ketiga sektor pertanian, kehutanan dan perikanan sebesar $13,73 \%$. Seiring perkembangan lingkungan strategis, peran laut menjadi signifikan serta dominan dalam mengantar kemajuan suatu negara. Jika kekuatan dan kekayaan laut diberdayakan, maka akan meningkatkan kesejahteraan dan keamanan suatu negara. Salah satu kekayaan laut yang perlu diperhatikan adalah 
sektor perikanan. Potensi sumber daya perikanan tangkap, budaya, dan pengolahan sebesar US\$ 29 miliar per tahun.Provinsi Jawa Timur merupakan salah satu provinsi dengan volume hasil perikanan tangkap di laut terbesar di Indonesia dengan produksi 362.624 ton/tahun.

Pemerintah Jawa Timur melansir bahwa konsumsi ikan Provinsi Jawa Timur tidak kurang dari 31,6 kg/kapita/tahun. FAO (Food and Agriculture Organization)memiliki standar minimal konsumsi ikan di dunia yaitu $30 \mathrm{~kg} /$ tahun.Dengan demikian, konsumsi ikan di Jawa Timur sudah melebihi standar FAO.Konsumsi ikan yang tinggi di Jawa Timur berkaitan erat dengan produksi ikan yang terjadi di wilayah ini. Jika Konsumsi ikan tinggi, maka idealnya produksi ikan di Jawa Timur juga harus tinggi. Data volume produksi perikanan tangkap di Jawa Timur mencapai $375.823,8$ ton per tahun yang merupakan angka tertinggi kedua di Indonesia [1, 2,3].

Kenyataanya, potensi setiap kabupaten/kota di Jawa Timur belum terjabarkan secara spesifik. Sehingga perlu dikaji lebih mendalam mengenai penyebaran potensi perikanan kabupaten/kota di Jawa Timur, disusun suatu sistem yang terintegrasi sehingga pada akhirya mampu memberikan value added bagi masyarakat setempat setiap kabupaten/ kota di Jawa Timur khususnya, dan meningkatkan laju pertumbuhan ekonomi provinsi Jawa Timur.

Penelitian ini akan melakukan analisis faktor untuk mereduksi variabel variabel pada perikanan laut dan perairan umum. Analisis ini merupakan kelanjutan dari pemetaan sektor perikanan Kabupaten/Kota di Jawa Timur dengan menggunakan Fuzzy K-means[4].Analisis faktor adalah sebuah teknik yang digunakan untuk mencari faktor-faktor yang mampu menjelaskan hubungan atau korelasi antara berbagai indikator independen yang diobservasi. Tujuan dari analisis faktor adalah untuk menggambarkan hubunganhubungan kovarian antara beberapa variabel yang mendasari tetapi tidak teramati, kuantitas random yang disebut faktor [5].

Analisis pada penelitian ini dibagi menjadi dua yaitu perairan umum dan perikanan laut. Masing-masing kelompok memiliki variabel yang sama yaitu jumlah nelayan/ petani ikan, jumlah
Rumah tangga/ perusahaan perikanan, jumlah Perahu/ kapal ikan yang digunakan, jumlah alat penangkap ikan, Produksi ikan, Nilai produksi ikan, Pengeluaran ikan, Angka Harapan Hidup (AHH), dan PPP (Pengeluaran Per Kapita).

Dengan menggunakan analisis faktor maka akan bisa dianalisis hubungan kedekatan antar variabel sektor perikanan laut dan perairan umum di Jawa Timur. Sehingga masing-masing faktor yang terbentuk akan memiliki karakkteristik tersendiri. Sehingga bisa diajukan acuan oleh pemerntah untuk membuat kebijakan yang lebih terarah karena penanganan akan disesuaikan dengan karakteristik masing-masing faktor yang sudah terbentuk.

\section{METODOLOGI}

Metode yang digunakan pada penelitian ini adalah analisis faktor dengan pendekatan varimax. Tujuan dari analisis faktor adalah untuk menggambarkan hubungan-hubungan kovarian antara beberapa variabel yang mendasari tetapi tidak teramati, kuantitas random yang disebut faktor [5]. Vektor random teramati $X$ dengann $p$ komponen, memiliki rata-ratadan matrik kovarian. Model analisis faktor adalah sebagai berikut:

$$
\begin{aligned}
& X_{1}-\mu_{1}=\ell_{11} F_{1}+\ell_{12} F_{2}+\ldots .+\ell_{1 m} F_{m}+\varepsilon_{1} \\
& X_{p}-\mu_{p}=\ell_{p 1} F_{1}+\ell_{p 2} F_{2}+\ldots .+\ell_{p m} F_{m}+\varepsilon_{p}
\end{aligned}
$$

Atau dapat ditulis dalam notasi matrik sebagai berikut :

$$
\boldsymbol{X}_{p x l}=\boldsymbol{\mu}_{(p x l)}+\boldsymbol{L}_{(p x m)} \boldsymbol{F}_{(m x l)}+\varepsilon_{p x l}
$$

dengan

$\mu_{i}={ }_{\text {rata-rata variabel } i}$

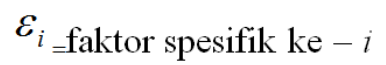

$F_{j=\text { common faktor ke- } j}$

$\ell_{i j}=$ loading dari variabel $\mathrm{ke}-i$ pada faktor ke- $j$

Bagian dari varian variabel ke $-i$ dari mcommon faktor disebut komunalitas ke $-i$ yang merupakan jumlah kuadrat dari loading 
variabel ke $-i$ pada mcommon faktor [5] dengan rumus :

$$
h_{i}^{2}=\ell_{i 1}^{2}+\ell_{i 2}^{2}+\ldots .+\ell_{i m}^{2}
$$

Tujuan analisis faktor adalah menggunakan matriks korelasi hitungan untuk 1)Mengidentifikasi jumlah terkecil dari faktor umum (yaitu model faktor yang paling parsimoni) yang mempunyai penjelasan terbaik atau menghubungkan korelasi diantara variabel indikator. 2.) Mengidentifikasi, melalui faktor rotasi, solusi faktor yang paling masuk akal. 3.) Estimasi bentuk dan struktur loading, komunality dan varian unik dari indikator. 4.) Intrepretasi dari faktor umum. 5.) Jika perlu, dilakukan estimasi faktor skor [6,7]

Penelitian akan dilaksanakan di Laboratorium Kelistrikan Kapal, Politeknik Perkapalan Negeri Surabaya. Adapun data sekunder yang akan digunakan dalam penelitian adalah data perikanan tangkap dari Dinas Kelautan Perikanan (DKP), dan data sektor perikanan Kabupaten/ Kota Jawa Timur yang disajikan oleh Biro Pusat Statistik (BPS) Provinsi Jawa Timur. Penelitian ini terdiri dari dua kelompok yaitu perikanan laut dan perairan umum. Masing-masing kelompok memiliki variabel yang sama, tetapi memiliki data yang berbeda.Variabel penelitian yang digunakan pada penelitian ini seperti pada Tabel 1 .

Tabel 1. Variabel penelitian

\begin{tabular}{|l|l|c|}
\hline No. & \multicolumn{1}{|c|}{ Variabel } & Satuan \\
\hline 1 & Nelayan/ petani ikan $\left(X_{1}\right)$ & Orang \\
\hline 2 & $\begin{array}{l}\text { Rumah tangga/ perusahaan } \\
\text { perikanan }\left(X_{2}\right)\end{array}$ & Unit \\
\hline 3 & $\begin{array}{l}\text { Perahu/ kapal ikan yang digu- } \\
\text { nakan }\left(X_{3}\right)\end{array}$ & Buah \\
\hline 4 & Alat penangkap ikan $\left(X_{4}\right)$ & Unit \\
\hline 5 & Produksi ikan $\left(X_{5}\right)$ & Ton \\
\hline 6 & Nilai produksi ikan $\left(X_{6}\right)$ & Rupiah \\
\hline 7 & $\begin{array}{l}\text { Pengeluaran per kapita maka- } \\
\text { nanikan }\left(X_{7}\right)\end{array}$ & Rupiah \\
\hline 8 & $\begin{array}{l}\text { Angka Harapan Hidup (AHH) } \\
\left(X_{8}\right)\end{array}$ & Tahun \\
\hline 9 & $\begin{array}{l}\text { PPP (Pengeluaran Per Kapita) } \\
\left(X_{9}\right)\end{array}$ & Rupiah \\
\hline
\end{tabular}


Cluster 3 merupakan kelompok yang memiliki potensi perikanan laut tertinggi di Jawa Timur. Kelompok ini terdiri dari 3 kabupaten yaitu Banyuwangi, Lamongan, dan Sumenep. Dilihat dari letak geografis anggota cluster memiliki area pantai atau laut yang sangat luas. Cluster 4 merupakan kelompok yang terdiri dari tiga kabupaten yaitu Gresik, Pamekasan, dan Kota Mojokerto. Pengelompokan ini cukup menarik karena Kota Mojokerto adalah Kabupaten yang terletak di perkotaan.

Tabel 2 Output analisis factor perikanan laut

\begin{tabular}{|c|c|c|c|c|c|c|}
\hline \multirow[b]{2}{*}{$\begin{array}{l}\text { Com- } \\
\text { ponent }\end{array}$} & \multicolumn{3}{|c|}{ Initial Eigenvalues } & \multicolumn{3}{|c|}{$\begin{array}{c}\text { Rotation Sums of Squared } \\
\text { Loadings } \\
\end{array}$} \\
\hline & Total & $\begin{array}{c}\% \text { of Vari- } \\
\text { ance }\end{array}$ & $\begin{array}{l}\text { Cumu- } \\
\text { lative \% }\end{array}$ & Total & $\begin{array}{c}\% \text { of } \\
\text { Varian-ce }\end{array}$ & $\begin{array}{l}\text { Cumula- } \\
\text { tive } \%\end{array}$ \\
\hline 1 & 5.097 & 56.630 & 56.630 & 4.98 & 55.412 & 55.412 \\
\hline 2 & 1.217 & 13.520 & 70.150 & 1.32 & 14.737 & 70.150 \\
\hline 3 & .806 & 8.953 & 79.102 & & & \\
\hline 4 & .703 & 7.811 & 86.913 & & & \\
\hline 5 & 609 & 6.770 & 93.683 & & & \\
\hline 6 & .262 & 2.915 & 96.598 & & & \\
\hline 7 & .179 & 1.989 & 98.587 & & & \\
\hline 8 & .095 & 1.057 & 99.645 & & & \\
\hline 9 & .032 & .355 & 100.00 & & & \\
\hline
\end{tabular}

Proses selanjutnya adalah dilakukan analisis faktor. Analisis faktor adalah sebuah teknik yang digunakan untuk mencari faktorfaktor yang mampu menjelaskan hubungan atau korelasi antara berbagai indikator independen yang diobservasi.

Tabel 3 nilai komponen analisis faktor

\begin{tabular}{|l|l|l|}
\hline \multirow{2}{*}{} & \multicolumn{2}{|c|}{ Component } \\
\cline { 2 - 3 } X1 & 1 & 2 \\
X2 & .913 & -.243 \\
X3 & .920 & -.014 \\
X4 & .965 & -.105 \\
X5 & .896 & -.116 \\
X6 & .604 & -.259 \\
X7 & .865 & -.099 \\
X8 & .650 & .227 \\
X9 & -.188 & .732 \\
\hline
\end{tabular}

Berdasarkan analisis faktor dengan menggunakan analisis factor maka didapatkan bahwa $70,150 \%$ persoalan perikanan laut yang terdiri dari Sembilan variabel bergantung pada dua faktor utama dan saling independen. Proses anaisis factor ini melalui proses rotasi dengan varimax.

Faktor pertama dibentuk oleh tujuh variabel yang teridiri dari jumah nelayan/petani ikan, jumlah rumah tangga/perusahaan perikanan, jumlah kapal penangkap ikan, jumlah produksi ikan, nilai poduksi ikan, dan pengeluaran ikan. Ketujuh variabel tersebut saling berkorelasi secara positif. Faktor ini membentuk 55,41\% dari variabel yang ada. Faktor kedua dibentuk oleh dua variabel yaitu angka harapan hidup dan pengeluran per kapita. Kedua variabel ini berkorelasi positif dan meupakan pembentuk indeks pembangunan manusia. Faktor ini membentuk $14,7 \%$ dari variabel yang ada

\section{- Perairan Umum}

Berdasarkan pengelompokan dengan menggunakan FuzzyK-Means Clustering terbentuk 3 kelompok. Cluster 1 terdiri dari Sembilan Kabupaten/ Kota di Jawa Timur yaitu Pacitan, Tulungagung, Malang, Lumajang, Bondowoso, Madiun, Ngawi, Gresik dan Surabaya. Cluster 2 ini terdiri dari 3 kabupaten/ kota di Jawa Timur yaitu Bojonegoro, Tuban dan Lamongan. Cluster ini merupakan cluster terbaik dalam pengoptimalan potensi perikanan tangkap pada perairan umum di Jawa Timur pada Tahun 2016.

Cluster 3 ini terdiri dari 26 Kabupaten/ Kota di Jawa Timur yaitu kabupaten/ kota Ponorogo, Trenggalek, Blitar, Kediri. Jember, Banyuwangi, Situbondo, Probolinggo, Pasuruan, Sidoarjo, Mojokerto, Jombang, Nganjuk, Magetan, Bangkalan, Sampang, Pamekasan, Sumenep, Kediri, Blitar, Malang, Probolinggo, Pasuruan, Mojokerto, Mojokerto, Mdiun dan Batu. Cluster 3 ini memiliki peringkat ke dua (menengah) dibandingkan dua cluster yang lain, karena cluster ini cukup baik dalam mengelola potensi perikanan tangkap pada perairan umumnya.

Proses selanjutnya adalah dilakukan analisis factor. Berdasarkan analisis factor dengan menggunakan analisis factor maka didapatkan bahwa $70,144 \%$ persoalan perairan umum yang terdiri dari Sembilan variabel bergantung pada dua factor utama dan saling independen. Proses analisis factor ini melalui proses rotasi dengan varimax. 
Tabel 4 Output analisis factor perairan umum

\begin{tabular}{|c|c|c|c|c|c|c|}
\hline \multirow[b]{2}{*}{$\begin{array}{l}\text { Com- } \\
\text { ponent }\end{array}$} & \multicolumn{3}{|c|}{ Initial Eigenvalues } & \multicolumn{3}{|c|}{$\begin{array}{c}\text { Rotation Sums of Squared } \\
\text { Loadings }\end{array}$} \\
\hline & Total & $\begin{array}{l}\% \text { of } \\
\text { Vari- } \\
\text { ance }\end{array}$ & $\begin{array}{l}\text { Cumula- } \\
\text { tive } \%\end{array}$ & Total & $\begin{array}{l}\% \text { of } \\
\text { Vari- } \\
\text { ance }\end{array}$ & $\begin{array}{c}\mathrm{Cu}- \\
\text { mula- } \\
\text { tive } \\
\% \\
\end{array}$ \\
\hline 1 & 5.096 & 56.625 & 56.625 & 4.987 & 55.409 & 55.409 \\
\hline 2 & 1.217 & 13.519 & 70.144 & 1.326 & 14.734 & 70.144 \\
\hline 3 & .806 & 8.952 & 79.096 & & & \\
\hline 4 & .703 & 7.812 & 86.908 & & & \\
\hline 5 & .609 & 6.772 & 93.680 & & & \\
\hline 6 & .262 & 2.913 & 96.593 & & & \\
\hline 7 & .179 & 1.993 & 98.585 & & & \\
\hline 8 & .095 & 1.059 & 99.645 & & & \\
\hline 9 & .032 & .355 & 100.000 & & & \\
\hline
\end{tabular}

Tabel 5 Nilai komponen analisis faktor

\begin{tabular}{|l|r|r|}
\hline \multirow{2}{*}{} & \multicolumn{2}{|c|}{ Component } \\
\cline { 2 - 3 } X1 & 1 & \multicolumn{1}{|c|}{2} \\
$\mathrm{X} 2$ & .913 & -.242 \\
$\mathrm{X} 3$ & .920 & -.014 \\
$\mathrm{X} 4$ & .965 & -.105 \\
$\mathrm{X} 5$ & .896 & -.116 \\
$\mathrm{X} 6$ & .604 & -.259 \\
$\mathrm{X} 7$ & .865 & -.099 \\
$\mathrm{X} 8$ & .650 & .227 \\
$\mathrm{X} 9$ & -.188 & .732 \\
& .039 & .761 \\
\hline
\end{tabular}

Berdasarkan Tabel 5, terbentuk dua faktor pertama. Faktor pertama dibentuk oleh tujuh variabel ya.ng teridiri dari jumah nelayan/petani ikan, jumlah rumah tangga/perusahaan perikanan, jumlah kapal penangkap ikan, jumlah produksi ikan, nilai poduksi ikan, dan pengeluaran ikan. Ketujuh variabel tersebut saling berkorelasi secara positif. Faktor ini membentuk 55,40\% dari variabel yang ada. Faktor kedua dibentuk oleh dua variabel yaitu angka harapan hidup dan pengeluran per kapita. Kedua variabel ini berkorelasi positif dan meupakan pembentuk indeks pembangunan manusia. Faktor ini membentuk $14,73 \%$ dari variabel yang ada.

\section{KESIMPULAN}

1. Berdasarkan hasil analisis faktor untuk perikanan laut dan perairan umum terbentuk dua faktor utama dengan nilai loading factor masing-masing $70,15 \%$ dan $70,14 \%$

2. Hasil analisis faktor Untuk Perikanan Laut Faktor pertama dibentuk oleh tujuh variabel yang teridiri dari jumah nelayan/petani ikan, jumlah rumah tangga/perusahaan perikanan, jumlah kapal penangkap ikan, jumlah produksi ikan, nilai poduksi ikan, dan pengeluaran ikan. Faktor kedua dibentuk oleh dua variabel yaitu angka harapan hidup dan pengeluran per kapita.

3. Hasil analisis faktor untuk perairan umum faktor pertama dibentuk oleh tujuh variabel yang teridiri dari jumah nelayan/petani ikan, jumlah rumah tangga/perusahaan perikanan, jumlah kapal penangkap ikan, jumlah produksi ikan, nilai poduksi ikan, dan pengeluaran ikan Faktor kedua dibentuk oleh dua variabel yaitu angka harapan hidup dan pengeluran per kapita

\section{DAFTAR PUSTAKA}

[1] BPS, Jawa Timur Dalam Angka 2016.

[2] Ardiansyah, M.A. 2014. "Pemetaan Potensi Perikanan Kabupaten/Kota Provinsi Jawa Timur 2011". Surabaya: ITS

[3] PPID. (24 Juni 2012). Konsumsi Ikan Masyarakat Jatim Terbesar. Kominfo Jatim. Halaman 1. Tersedia: http://kominfo. jatimprov.go.id/watch/31496 (10 Oktober 2013).

[4] Farizi R, dan Norromadani. (2016). Pemetaan sector perikanan laut Kabupaten/ Kota Jawa Timur dengan metode fuzzy k-means clustering. Master 2016 vol.01

[5] Johnson, R.A. and Winchern, D.W. 2007. "Applied Multivariate Statistical Analysis". Pearson Education International. USA

[6] Sharma, S. 1996. Applied Multivariate Techniques, New-York: John Wiley \& Sons, Inc.

[7] Hair, J. F., Black, W. C., Babin, B. J., Anderson, R. E. (2010). Multivariate Data Analysis Seventh Edition. 
Halaman ini sengaja dikosogkan 